\title{
USING PICTIONARY GAME TO INCREASE LEARNERS' VOCABULARY MASTERY IN ENGLISH LANGUAGE INSTRUCTION
}

\author{
Welliam Hamer, Ledy Nur Lely ${ }^{1}$ \\ ${ }^{1}$ English Education Study Program of Teacher Training and Education Faculty, Universitas Sultan Ageng Tirtayasa
}

\section{ARTICLE INFO}

Keywords:

Pictionary Game

Vocabulary Mastery

English İnstruction

\begin{abstract}
This article aims at sharing information on how pictionary game is used to increase the learners' vacabulary mastery in the process of teaching and learning. It is clear that vocabulary is one of components of English language. When the learners are reading, they need to master vocabulary related to certain topic. Therefore vocabulary is important thing in learning English. However, mastering English vocabularies is not easy. English is foreign language in which learning English is often considered to be difficult to comprehend. This problem can be seen from the unsatisfactory result when learning English. The learning processs commonly used in the classroom just puts the teacher as a center of learning. It means that the teacher always dominates him/herself to teach, not to focus on how the learners learn effectively. This makes the learners passive and less interested in following the course of learning. In fact the learners' interest is the most important factor in the study. Interest can be developed if the learning process run with fun, vary, and conducive athmosphere. There are many factors that can support the existance of an increase in the study, i.e. teachers, learners, materials, media, methods, and other learning sources. One factor that can help the learners learn vocabulary is the use of pic tionary game. In this study, pictionary game is a classic game of drawing and guessing pictures. Pictionary game can also increase the imag ination of learners, where learners are asked to draw according to the word given by the teachers. Things that are needed to play pictionary game are a list or card of vocabulary items, whiteboard, calkboard, or smart bo ard and markers. Pictionary game will help learners to get involved in classroom activities. Other advantages of using pictionary game can be concluded that it provides fun language practice in the various language skills.
\end{abstract}

This is an open access article distributed under the terms of the Creative Commons Attribution 4.0 Intemational License, which permits unrestricted use, distribution, and reproduction in any medium, provided the original work is properly cited. @ 2019 Welliam Hamer, Ledy Nur Lely

\footnotetext{
1 Corresponding author's address: English Education Study Program of Teacher Training and Education Faculty, Universitas Sultan Ageng Tirtayasa, Banten, Indonesia

e-mail: welliamhamer@untirta.ac.id, Ledy@untirta.ac.id
} 


\section{INTRODUCTION}

Instruction is the arrangement of information and environment to facilitate learning. By environment, we mean not only where instruction takes place but also the instructional media, methods, and other teaching equipments needed to convey information and guide the learners' study. Therefore, the arrangement of information and the environment is normally the responsibility of the teachers. The choice of the strategy of instruction determines the environment (the methods, media, and other facilities) and the way information is used (Heinich et al., 1996).

Dealing with the statement above, it can be said that the teachers play an important role to faciliate the learners by involving the selection, arrangement, and delivery of information in an appropriate environment (instructional media, materials, and teaching methods) and the way the learners interact with that information in the teaching and learning activities in the classroom. Therefore, it needs to consider that the teachers should be aw are of the learners that they are supposed to be actively involved in the process of teaching and learning through integrated language teaching and learning.

It can be inferred that an English teacher must be creative and imaginative to lead his/her learners to be able to learn English. He or she should be able to create the appropriate atmosphere. One of the efforts that the teacher must do is to promote the quality of applying the instructional media/technique. This is intended to achieve one of the ultimate aims of instructional aspect, to enable the learners to express their ideas in English. Considering the effectiveness of teaching and learning, the teacher should also notice the suitable strategies in designing and managing the learners in teaching-learning activities.

It is true to say that mastering English skills require vocabulary mastery so that the idea to say it can be implemented well. Vocabulary learning should be done effectively, actively, creatively as well as fun so that it does not make the learners saturated and bored. Therefore, the teachers are required to do learning and teaching vocabulary with creative, until became more meaningful to attract the learners to learn it. Good learning is to involve all activities of learning, i.e. it will be better if the teachers facilitate the learners with various instructional media and teaching methods adequately. Beside that, when delivering materials about vocabulary, it should be done by arrousing the learners' motivation in order that they feel happy and could actively involve themselves in following the learning and teaching activities. Therefore, the learners do not just limit themselves to sit in the place and listen to the explanation from the teachers. They should be invited to initiate their active participation to interact with the teacher and their friends as well.

Vocabulary is one of English components as a core of ability to listen, to speak, to read and to write. Without having ample vocabulary and the right strategy to obtain a new vocabulary, the learners will get difficulties to optimize their own abilities in learning English. For instance, the learners are still confused to w rite what they see or they want, they are unable to communicate by using English, and they do not understand what the teachers say. Even when the materials delivered by teachers in class, most of the learners do not understand and they do not understand the meaning of difficult words. The learners still get difficulties to learn or memorize new vocabularies. The learners do not feel confident to communicate with their teachers when answering questions and fell hesitate to talk with their friends in the classroom activities as well as outside the classroom. The learners also cannot translate the difficult words, phrase, sentences, and paragraphs from English to Indonesian.

Looking at the learners' difficulties when learning vocabulary above, it can be said that the teacher should be able to choose the solutions to overcome the obstacles of inadequate vocabulary in order that the learners are able to learn English well. So, one of the instructional media/methods to facilitate the learners in increasing their vocabulary mastery is pictionary game. It is necessary to inform that pictionary game can make the learners learn English vocabulary easily. By using 
pictionary game, it can increase the learners' motivation to practice their English enthusiastically as well as create the atmosphere of teaching and learning English more interesting and fun.

\section{LITERATURE REVIEW}

\section{The Nature Of Vocabulary}

Vocabulary is a major part of almost every standardized test, including reading achievement tests, college entrance exams, and armed forces and vocational placement test (Nist and Mohr, 2002). Vocabulary is very important, it is one of the measurements of language learners whether someone is successful in learning language or not. Then, the teaching of vocabulary has to communicative effectively. Learners should be able to make themselves understand and use their current proficiency. They should try to avoid confusion in the message due to the mastery of vocabulary.

In addition, the National Reading Panel (in Hiebert and Kamil, 2005) states that vocabulary is not a developmental skill or one that can ever be seen as fully mastered. The expansion and elaboration of vocabularies is something that extends across a lifetime. Vocabulary is the knowledge of meanings of words used to express ideas, feeling, and information to each people around the world.

Meanwhile, Nunan (2015) says that vocabulary is useful to keep a word list of the 1.000 most common words on hand and use it as a reference tool. Vocabulary is foundation or a basic of a language that an individual can use when writing or speaking, and to assign meaning when listening or reading.

Based on the explanation above, it could be concluded that vocabulary is a list of words with their meanings that accompanies a text book in a foreign language. Then, it is important to teach vocabulary first to the learners. Vocabulary plays a significant role in supporting the mastery of language skills such as listening, speaking, reading and writing which are called four skills of language. In order to communicate well in language, learners should acquire an adequate number of words and should know how to use them accurately.

There are many kinds of instructionl media as well as strategies and/or techniques in presenting vocabulary to the English learners. It can be summarized that the ways in teaching vocabulary in English classrooms depend on the teacher how to select and use the best technique in order to make learners feel enjoyable and not to make them feel bored, because teacher as a facilitator has to be able to assist the learners to choose the solutions on each problem in learning and teaching vocabulary.

\section{The Importance of Vocabulary}

Vocabulary has an importance function in language. By having a great number of vocabularies, the learners are expected to master four skills in English such as listening, reading, speaking, and writing. It means that the learners can listen and understand the materials easily delivered by the teacher. When reading English texts, the learners are able to comprehend easily without using dictionary so that they can enjoy reading. Then, the learners can also initiate and/or practice their productive skills (speaking and writing) confidently and naturally.

Stahl and Nagy (2005) revealed the same thing about the importance of vocabulary between people who understand the vocabulary and people who do not understand the vocabulary. They said that a person who knows more words can speak, and even think, more precisely about the world. A person who knows the terms scarlet and crimson and azure and indigo can think about colors in a different way than a person who is limited to red and blue. A person who can label someone as pusillanimous or a recreant can better describe a person's cow ardly behavior. Words divide the world; the more words we have, the more complex ways we can think about the world. 
As we know that vocabulary is the basic element in language, it means that it is necessary to learn vocabulary first when we start learning language, especially English because vocabulary is the first or beginning step or stages when we learn the language. In other words, vocabulary has an important role and should be given from the beginning stages in order to make the learners master in vocabulary. Therefore, the learners who have adequate vocabulary will be able to use the suitable or appropriate words in sentences for each situation in making communication to other people.

Learners often instinctively recognize the importance of vocabulary to their language learning. Teaching vocabulary helps learners understand and communicate with others in English. View vocabulary items as a boring list of words that must be defined and memorized by the learners, lexical forms are seen in their central role in contextualized, meaningful language.

Similarly, according to Simpson (2011), lexical knowledge is central to communicative competence and to the acquisition of a second language. If we do not know the vocabulary then we will have difficulty to know the science of language. He further stated that the term lexis, from the ancient Greek for 'w ord' refers to all the words in a language, the entire vocabulary of a language.

\section{The Aspects In Learning Vocabulary}

There are many ways that will help the learners expand their vocabulary and proficiency, they are as follows:

a. Word Clasess

According to Thornbury (2002), a word is a microcosm of human consciousness. All languages have words. Language emerges first as words, both historically, and in terms of the way each of us learns our first and any subsequent langauges. Word is classified based on its functional category, it is called part of speech. Kinds of part of speech are: noun, pronouns, adjective, verb, adverb, preposition, conjunction, and interjection.

b. Word Families

We have seen how words may share the same base of root, but take different endings. A word that results from addition of an affix to a root, and which has a different meaning from the root, it is called derivative. For example: players, replay, and playful are each derivative of play. Derivatives and inflexions are both formed by the process of affixation. Affixes consist of suffixes, such as -ful and -er are at the end of a word. Meanwhile, prefixes, such as re-, un-, pre, de- are at the beginning of a word.

c. Word Formation

In linguistics, an affix is a morpheme that is attached to a word stem to form a new word or word formation. There are several kinds of that, such as: compounding, blending, conversion, and clipping. Compounding is the combining of two or more independent words, as in the case of second-hand, word processor, paperback, and so on. Then, two words can be blended to form one new one, for instance: breakfast + lunch = brunch; information + entertainment = infotainment. Or a word can be co-opted from one part of speech and used as another, a process called conversion. Typically nouns are converted into verbs as in "let's brunch tomorrow". But other parts of speech can be converted as well, for example: she upped and left. Finally, new words can be coined by shortening or clipping longer words, such as: flu (from influenza), email (from electronic mail) and dorm (from dormitory).

d. Word Meaning

There are at least three word meanings, they are: synonyms which are items that mean the same, or nearly the same, for example: bright, clever, smart may serve as synonym of diligent. On the other hand, antonyms are items that mean the opposite; rich is an antonym of poor. Then, hyponyms are items that serve as specific examples of a general concept; dog, lion, mouse are hyponyms of animals. 


\section{The Assessment of Vocabulary}

According to Brown (2004), assessment is an ongoing process that encompasses a much wider domain. Whenever a learner responds to a question, offers a comment, or tries out a new word or structure, the teacher subconsciously makes an assessment of the learner's performance. Written work - from a jotted-down phrase to a formal assay - is performance that ultimetely is assessed by self, teacher, and possibly other learners. Reading and listening activities usually require some sort of productive performance that the teacher implicitly judges, however peripheral that judgement may be. A good teacher never ceases to assess learners, whether those assessments are incidental or intended. Meanwhile, tests are a subset of assessment; they are certainly not the only form of assessment that a teacher can make. Tests can be useful devices, but they are only one among many procedures and tasks that the teachers can ultimately use to assess learners.

In line with the statements above, it can be said that most of classroom assessment is formative assessment; evaluating learners in the process of forming their competencies and skills with the goal of helping them to continue that grow th process. The key to such formation is the delivery by the teacher and internalization by the learners of appropriate feedback on performance, $w i t h$ an eye toward the future continuation or formation of learning. In other words, for all practical purposes, virtually all kinds of informal assessment should be formative. They have as their primary focus the ongoing development of learner's language. So, when the teachers give the learners a comment or a suggestion, or call attention to an error, that feedback is offered in order to improve the learners' langauge ability.

Similarly, Frazee and Rudnitski (1995) state that formative assessment is ongoing, and provides feedback and information on processes. Formative assessment also provides information on development over time. It differs from summative assessment in that summative assessment provides feedback on products and occurs at the end or summation of an activity. Summative assessment aims to measure, or to summarize, what a learner has grasped, and typically occurs at the end of a course or unit of instruction. A summation of what a learner has learned implies looking back and taking stock of how well that learner has accomplised objectives, but does not necessarily point the way to future progress. Final exams in a course and general proficiency exams are examples of summative assessment.

Reffering to the statements above, it can be inferred that assessment is a process of collecting the data that gives the description about learning development of the learners. The teacher must concern about it in order to determine whether the learners really have experienced the process of teaching and learning or not. The description is needed during the teaching-learning activity, so that the assessment is not only conducted at the end of period and/or semester, but it is also conducted during the activities.

Teacher who wants to know the learners' development of learning English should collect the data from the real activity while the learners use English. The data are taken from the learners' activity when they are learning English whether it happens in the class or outside it. Since vocabulary in one of English components to support the learners' competence in English skills, the mastery of vocabulary is badly needed to be considered in determining the quality of their English. In other words, it is necessary to know that the teachers are expected to apply vorious ways to assess their progress in learning, especially when learning to increase their vocabulary mastery.

By doing so, assessing vocabulary should have the same priority as other skills in that the important pillars of testing (validity, reliability, practicality, authenticity, transparency, and security) need to be considered in designing and evaluating tests of lexical knowledge and use. Therefore, measurement of language use currently cannot tell the size of a learner's vocabulary, 
but they indicate how skillful the learner is in drawing on vocabulary knowledge to perform communicative tasks.

According to Thornbury (2002), testing vocabulary has a useful "backwash" effect: if learners know they are going to be tested on their vocabulary learning, they may take vocabulary learning more seriously. it means that testing vocabulary motivates learners to review vocabulary in preparation for a test. It also provides an excuse for further, post-test, review - when, for example, the teacher goes over the answers in class. In this way, testing can be seen as part of the recycling of vocabulary generally. In fact, the only difference between many recycling exercises and tests is that only the latter are scored.

Furthermore, according to Daller (2007), the most commonly used measurement of vocabulary is rating scale, where the vocabulary component is one of several subscales. The vocabulary subscale typically has four or five levels ranging from very poor knowledge of vocabulary to an excellent, sophisticated, and appropriate use vocabulary. There are five subscales in their ESL composition profile - content, organization, vocabulary, language use and mechanics. Each subscale has four levels and the vocabulary subscale's levels are as follows:

\begin{tabular}{ccl}
\hline No & Level & \multicolumn{1}{c}{ Criteria } \\
\hline 1 & $20-18$ & $\begin{array}{l}\text { Excellent to very good; sophisticated range, effective word/idiom (form, } \\
\text { choice, and usage). Word form mastery; appropriate register. }\end{array}$ \\
\hline 2 & $17-14$ & $\begin{array}{l}\text { Good to average; adequate range. Occasional errors of word/idiom (form, } \\
\text { choice, and usage) but meaning not obscured. }\end{array}$ \\
\hline 3 & $13-10$ & $\begin{array}{l}\text { Fair to poor; limited range, frequent errors of word/idiom (form, choice, } \\
\text { and usage). Confused or obscured meaning. }\end{array}$ \\
\hline 4 & $9-7$ & $\begin{array}{l}\text { Very poor; essentially translation. Little knowledge of English vocabulary, } \\
\text { idioms, and word form. Not enough to evaluate. }\end{array}$ \\
\hline
\end{tabular}

\section{The Nature of Pictionary Game}

It is true to say that game is very important in teaching learning activities. It is very useful in understanding the words or sentences. In teaching English, in the case of vocabulary mestery, the teachers usually prepare some materials for their learners. According to Mutiah (2010), game is an education because giving a sense of satisfaction, excitement and happiness. The learners' interest and motivation can be increased under teaching vocabulary with game.

The game is activities that contain toys and plays. The play is the learning process. It means that game can increase learners' interest and their activities in following series of events in the process of learning and teaching in the classroom. Therefore, the functions of game are as follows:

1. Giving knowledge to learners through the learning process of plays.

2. Stimulating the development of the thought, copyright and language to be able to cultivate attitude, mental, as well as good manners.

3. Creating an environment play; giving a sense of security and fun.

4. Improving the quality of learning. Playing game has an important role in the development of learners on almost all areas, i.e. cognitive ability, affective ability psychomotoric ability, language ability, and social ability.

Referring to the information stated above, it can be said that game is very necessary to increase learners' vocabulary mastery. Therefore, the advantages of game are as follows:

1. Exercise motoric ability.

2. Exercise concentration. 
3. Socialize advance ability (including competition).

4. Exercise speaking ability.

5. Add the insight.

6. Develop ability to problem solving.

7. Develop leadership of the soul.

8. Develop knowledge about the norm and value judgment.

9. Increase confidence.

Furthermore, pictionary game is a game that represents the picture of the word that should be guessed. Pictionary game is one of the most popular games. It can be used to teach vocabulary. Pictionary game was invented by a man named Robert Angel at the age of 24 years. In 1986, Pictionary game was introduced by him. This game became more popular since then as a meaningful tool that can be used to teach English, especially in increasing the learners' vocabulary.

From the information stated above, it can be said that pictionary game can be used as excellent teaching tool for developing communication and creative thinking skills; it is suit able to reinforce ideas in other subject matters for those learners who are visual learners; it can develop and reinforce any number of facts, figures, or concepts; pictionary rules will focus on the development of creative thinking. Additionally, Efiza (2017) informs that pictionary game is a game that involves the learners in guessing words or phrases from drawings. This game works in teams and each member of the team takes turns to be the artist.

There are many materials used in pictionary game, such as: a list or cards of vocabulary items, whiteboard, chalkboard, or smart board and markers. In addition, Using this pictionary game will help the learners to get involved in classroom activities. Since pictionary is a game that requires learners to work in a team, it will give learners opportunity to learn English in interactive ways.

\section{DISCUSSION}

\section{The Instruction and Implication of Pictionary Game}

To play pictionary game, each team moves a piece on a game board formed by a sequence of squares. Each square has a letter or shape identifying the type of picture to be drawn on it. The objective is to be the first team to reach the last space on the board. To achieve this, a player must guess the word or phrase being drawn by their partner, or if the player lands on an "all play" square, one player from each team attempts to illustrate the same concept simultaneously, with the two teams racing to guess first. The first player is to land and guess correctly at the finish wins.

In addition, in pictionary game, the team chooses one person to begin drawing; this position rotates with each word. The drawer chooses a card out of a deck of special pictionary cards and tries to draw pictures which suggest the word printed on the card. The pictures cannot contain any numbers or letters, nor can the drawer use verbal clues about the subject they are drawing. The teammates try to guess the word the drawing is intended to represent.

There are five types of squares on the board, and each pictionary card has a list of five words printed on it. Players must then draw the word which corresponds to the square on the board on which the team's marker is:

\begin{tabular}{||l|l||}
\hline & Subject \\
\hline \hline $\mathbf{P}$ & Person/Place/Animal \\
\hline \hline $\mathbf{O}$ & Object \\
\hline
\end{tabular}




\begin{tabular}{|c|l||}
\hline A & Action \\
\hline \hline D & Difficult (words which are difficult to represent in a drawing) \\
\hline \hline AP & All Play \\
\hline & $\begin{array}{l}\text { Appears in certain versions. Player may pick a card and choose which word they wish to } \\
\text { draw from the five given. }\end{array}$ \\
\hline
\end{tabular}

Based on the diagram above, it can be said that AP category (and a random selection of checkmarked words in other categories) are designated as "All Play". For "All Play," the teams compete against each other. Each team designates a player whose purpose will be to draw pictures. The team that guesses the word first gets to advance and take the next turn. If none of the teams guess the word, the turn passes to whichever team should have been next. One may not point or gesture to an object.

From the information stated above, it can be summarized that there are some instructions to apply pictionary game in the classroom, there are as follows:

1. Learners are divided into group. The number of groups can be depending on the number of learners in the classroom and also can be also divided based on the seat.

2. The teacher explains the rules of pictionary game.

3. Each of the groups is given a word to draw.

4. Each of the groups determines the others to draw and also to illustrateevery word given by the teacher. The others can be the learners who sit down in front of the classroom and/or in the back side.

5. Teacher who puts collection of that word will draw in the front desk, along with a blank sheet of paper for drawing a number of many words to each of the learners.

6. After all learners are ready, the teacher gives w arning to start and each of the learners starts to play it.

7. After a warning, one member of each group begins to take one of the cards and begin to draw, and then tell the members of the group to guess (students who are drawing only answer "yes" if true and "no" if false).

8. Each learner as members of the group takes turns to go forw ard to take one of the card words and draws to guess by members of the group.

9. The winner is the most and the fastest group when guessing the words correctly.

By doing so, it is necessary to say that there are many advantages of using this pictionary game in language learning, for instance: pictionary game is very effective for visual learners or individuals. Therefore, it provides language practice in the various English skills, i.e. listening, speaking, reading, and writing; depending on the variation of the game. Moreover, pictionary game also encourages the learners' cooperative learning in the teamwork. However, there are also some weaknesses of using pictionary game, for examples: it only provides visual learning style. Some learners do not feel comfortable to work in a group. Pictionary game may also be difficult and sometimes frustrating for the learners who cannot draw well.

\section{CONCLUSION}

After having discussed the principles of using pictionary game as well as the implementation process of playing pictionary game in the classroom with the purpose is to increase the learners' vocabulary mastery, it can be inferred that pictionary game as instructional methods and/or teacnique is one of many interesting vocabulary games in English instruction activities. 
Similarly, in line with the review of several points discussed above, it can be concluded that pictionary game is effective and enjoyable to increase the students' vocabulary achievement. It means that the learners who are better in vocabulary will be easier to improve their quality of learning English. Therefore, pictionary game can be used as an excellent teaching tool for developing communication and active thinking skills as well.

Based on the conclusions above, there are some recommendations that can be given in relation to the context of using pictionary game in English language instruction. Firstly, English teacher should implement pictionary game for teaching vocabulary, since it is more enjoyable for the learners and they could learn about vocabulary without any pressure. In other words, using pictionary game does not only have fun, but also it can be an alternative strategy and/or technique to facilitate learners to increase their vocabulary mastery. Secondly, The English teacher should be able to explain the rules of game clearly and select the game which is appropriate with the materials. Finally, it is true to say that the materials as well as other learning sources cannot be separated with the use of instructional media and methods when teaching and learning vocabulary.

Thus, in line with the information stated above, It can be inferred that the English teacher should review the materials that have been taught intensively before he or she gives new material so that the learners are able to accept their achievement easily and obviously. In other words, it is also necessary to recommend that in order to ensure the delivery of the materials to the learners, the English teacher should design group work, pair work, and other teaching and learning strategies/techniques so that the learners are able to interact with each other and take good advantages of their learning process, especially while they are learning to increase their vocabulary mastery.

\section{REFERENCE}

Brown, H. Douglas. 2004. Langauge Assessment: Principles and Classsroom Practice. United States of America. Longman.

Daller, Helmut., et al. 2007. Modeling and Vocabulary Knowledge. New York: Cambridge University Press.

Efiza, Lidya. 2017. Improving Students' Vocabulary Mastery through Pictionary Board Game. Jurnal Pendidikan Al-Ishlah. Volume.9, No.2.

Frazee, Bruse M. and Rudnitski, Rose A. 1995. Integrated Teaching Methods; Theory, Classroom Applications, and Field-Based Connections. United States of America: Delmar Publishers.

Heinich, R., et al. 1996. Instructional Media and Technologies for Learning. United States of America: Prentice-Hall, Inc.

Hiebert, E. and Kamil, M. 2005. Teaching and Learning Vocabulary. London: Laurence Erlbaum Associates.

Mutiah, Diana. 2010. Psikologi Bermain Anak Usia Dini. Jakarta: Penerbit Kencana.

Nist, S.L. and Mohr, C. 2002. Improving Vocabulary Skills, West Berlin: Townsend Press Inc.

Nunan, D. 2015. Teaching English to Speakers of Other Languages. New York: Routledge.

Simpson, James. 2011. The Handbook of Applied Linguistics. London: Routledge.

Stahl, Steven A. and Nagy, William E. 2005. Teaching Word Meaning. New Jersey: Lawrence Relbaum Associates, Inc.

Thornbury, S. 2002. How to Teach Vocabulary. England: Pearson Education Limited. 